\title{
Advances in rheumatology: new targeted therapeutics
}

\author{
Paul P Tak ${ }^{1 *}$ and Joachim R Kalden²
}

\begin{abstract}
Treatment of inflammatory arthritides - including rheumatoid arthritis, ankylosing spondylitis, and psoriatic arthritis - has seen much progress in recent years, partially due to increased understanding of the pathogenesis of these diseases at the cellular and molecular levels. These conditions share some common mechanisms. Biologic therapies have provided a clear advance in the treatment of rheumatological conditions. Currently available TNF-targeting biologic agents that are licensed for at least one of the above-named diseases are etanercept, infliximab, adalimumab, golimumab, and certolizumab. Biologic agents with a different mechanism of action have also been approved in rheumatoid arthritis (rituximab, abatacept, and tocilizumab). Although these biologic agents are highly effective, there is a need for improved management strategies. There is also a need for education of family physicians and other healthcare professionals in the identification of early symptoms of inflammatory arthritides and the importance of early referral to rheumatologists for diagnosis and treatment. Also, researchers are developing molecules - for example, the Janus kinase inhibitor CP-690550 (tofacitinib) and the spleen tyrosine kinase inhibitor R788 (fostamatinib) - to target other aspects of the inflammatory cascade. Initial trial results with new agents are promising, and, in time, head-to-head trials will establish the best treatment options for patients. The key challenge is identifying how best to integrate these new, advanced therapies into daily practice.
\end{abstract}

*Correspondence: P.P.Tak@amc.uva.nl

'Department of Medicine, Division of Clinical Immunology and Rheumatology F4-105, Academic Medical Center/University of Amsterdam, P.O. Box 22700,

1100 DE Amsterdam, The Netherlands

Full list of author information is available at the end of the article

\section{Introduction}

Recent advances in the treatment of inflammatory arthritides - which include rheumatoid arthritis (RA), ankylosing spondylitis (AS), and psoriatic arthritis (PsA) - have resulted from greater understanding of the pathogenesis of these diseases. Cellular-level and molecular-level research has revealed that these diseases share some common mechanisms [1]. Most critically, the proinflammatory mechanisms of these diseases are associated with progressive joint destruction early in the disease course [2].

In the present article, we review insights into the management of inflammatory arthritides that have been gained from experience with the first generation of TNF inhibitors. We then discuss newer biologic agents as well as novel targeted small molecules that act on signalling pathways, all of which are expanding our knowledge of inflammatory arthritides and providing more comprehensive management options.

\section{Lessons learned from TNF inhibitors}

The development of biologic agents that selectively block cytokines has provided a major advance in the treatment of inflammatory arthritides [3,4]. TNF is a proinflammatory cytokine known to be present in higher concentrations in patients with RA, AS, and PsA. This cytokine plays a dominant role in the inflammatory cascade underlying various inflammatory disorders [5-8]. TNF is both an autocrine stimulator and a potent paracrine inducer of other inflammatory cytokines, including the interleukin family [8].

To date, three TNF-targeting agents have dominated the biologic management of RA, AS, and PsA. Etanercept, a dimeric fusion protein, consists of the extracellular portion of the human p75 TNF receptor linked to the Fc region of human $\operatorname{IgG}_{1}[9,10]$. Infliximab, a chimeric human-murine monoclonal antibody, binds to TNF and consists of human constant and murine variable regions. Adalimumab is a recombinant human monoclonal antibody specific to TNF $[11,12]$. All three anti-TNF therapies have well-demonstrated efficacy in RA, AS, and PsA $[9,11,12]$. This section focuses on these three agents, for which the most data exist. 
In RA (for which most data have been accrued), early treatment with any one of these antagonists in combination with methotrexate (MTX) leads to low disease activity or remission in a considerable percentage of patients [13-15]. TNF inhibitors can potentially prevent radiological progression and thereby prevent disability. However, the pharmacokinetics and binding profiles of these agents are different [1]. Nevertheless, randomised clinical trials (RCTs) in RA strongly suggest that all three TNF inhibitors effectively reduce signs and symptoms, improve physical function, and inhibit progression of structural damage.

According to the manufacturers, an estimated 1,136,000 patients have been exposed to infliximab, 500,000 patients to etanercept, and 370,000 patients to adalimumab worldwide since these products became commercially available. The regular monitoring requirements for TNF inhibitors are less stringent than those required for many conventional disease-modifying antirheumatic drugs (DMARDs). TNF inhibitors are commonly used in combination with conventional DMARDs, however, so most patients will still require monitoring.

\section{Safety}

Bacterial infections, including sepsis and pneumonia, invasive fungal infections, and other opportunistic infections (for example, pneumocystosis, candidiasis, listeriosis, aspergillosis), have been reported with the use of TNF inhibitors $[9,11,12]$. Reactivation of latent tuberculosis following treatment has led to the introduction of preinitiation screening procedures, which have successfully reduced the number of reported cases $[16,17]$. The risk of reactivation of latent tuberculosis is, of course, dependent on the incidence of latent infection and is associated with all TNF inhibitors [18,19]. Some registry data, however, suggest that the risk may be lower with etanercept [20-22]. In RA patients, risk factors include active longstanding disease, age, country of origin, history of exposure to a person with tuberculosis, concomitant use of immunomodulators, and disease activity [23]. Physicians should remain alert to the development of symptoms related to tuberculosis or other infections.

Owing to adverse effects observed during clinical trials, patients with congestive heart failure should be closely monitored if they are receiving TNF inhibitors $[9,11,12]$. Other rarely reported conditions possibly related to use of TNF inhibitors include demyelinating disease, seizures, aplastic anaemia, pancytopaenia, and drug-induced lupus $[9,11,12]$. Physicians should remain vigilant for the development of these conditions [16].

\section{Formation of antibodies}

The formation of antibodies to biologic agents is a significant issue because antibodies have the potential to reduce the efficacy of the agent or to cause adverse events [10]. All three TNF inhibitors have been associated with the development of antibodies, although etanercept does not appear to generate neutralising antibodies [9-12, 24-26]. The use of MTX in combination with TNF inhibitors appears to reduce the incidence of antibody formation $[10-12,24]$.

In a cohort study of 53 patients receiving etanercept for AS without MTX, mean etanercept levels in responders and nonresponders at 12 and 24 weeks were similar, and no antibodies to etanercept were detected [27]. No correlation was found among etanercept levels, formation of antibodies to etanercept, and clinical response. Conversely, in a 54-week cohort study of 38 patients receiving infliximab for AS, detection of antibodies to infliximab was associated with undetectable serum trough infliximab levels and reduced response to treatment [28].

\section{Shared mechanisms}

A look at the cellular and molecular levels of diseases in rheumatology demonstrates that such diseases share common mechanisms and may be more closely related than previously recognised. Rigorous studies have examined the mechanisms of action of the anti-TNF inhibitors, particularly infliximab and etanercept; however, many questions remain unresolved [1]. For example, although both infliximab and etanercept are useful in the treatment of peripheral arthritis and AS, there appear to be differences in their effects at the cellular level $[29,30]$. Moreover, while their actions in AS have yet to be fully elucidated, the long-lasting suppression of T-cell function apparent during treatment with infliximab suggests that neutralisation of soluble TNF cannot be the only mechanism [29]. Possible mechanisms generally fall into two categories: those mediated by blockade of the TNF receptor, and those mediated by induction of transmembrane TNF. Several mechanisms probably act simultaneously.

To what extent various mechanisms contribute to drug efficacy remains an open question. All of the anti-TNF agents bind to transmembrane TNF and could theoretically induce both complement-dependent cytotoxicity and antibody-dependent cellular cytotoxicity, although at lower levels for etanercept compared with the anti-TNF agents infliximab and adalimumab [1]. The roles of apoptosis and inflammation reversal for reducing cellularity in rheumatoid synovial tissue during anti-TNF therapy are unclear [1]. A study by Wijbrandts and colleagues analysed apoptosis in peripheral blood and synovial tissue within 24 hours of treatment with infliximab in patients with RA. There were no signs of apoptosis induction in peripheral blood monocytes or lymphocytes after infliximab treatment. These results support the view that the rapid decrease in synovial 
cellularity observed after initiation of anti-TNF therapy cannot be explained by apoptosis induction at the site of inflammation [31].

\section{Routes of administration}

The TNF inhibitors all require parenteral administration, either intravenously (infliximab) or via subcutaneous injection (etanercept, adalimumab) [4]. The availability of different formulations allows tailoring of treatment to the individual and ensures that the patient is receiving maximal benefit with minimal negative impact on their quality of life. Although some patients appreciate the control offered by self-administration of subcutaneous injections, others do not like to self-inject. Intravenous drugs can be inconvenient because of the need for regular hospital visits, but some patients desire regular contact with medical professionals. The decision on whether to use an intravenous or subcutaneous product should be based on the clinician's and patient's goals for treatment.

Intravenous administration allows high serum concentrations to be rapidly achieved, and therefore offers the potential for fast, complete suppression of inflammation $[32,33]$. Rapid improvement in signs and symptoms has been observed following the usual clinical dose of infliximab $(3 \mathrm{mg} / \mathrm{kg})$ in RA patients [34]. Within 48 hours of administration, patients experienced significant improvements in the mean duration of morning stiffness, patient assessment of pain, physician global assessment of arthritis, and patient global assessment of arthritis compared with baseline measurements. Studies using a high-dose infusion of infliximab $(10 \mathrm{mg} / \mathrm{kg})$ in RA patients have shown significant reductions in C-reactive protein levels [35,36], improvements in Disease Activity Score (DAS) and American College of Rheumatology (ACR) response [37], and significant reductions in bone resorption as measured by $\beta$-CrossLaps, a predictor of annual bone loss in RA, as soon as 24 hours post infusion [37]. The benefits of higher doses, however, must be weighed against accompanying increases in side effects. Additionally, infliximab therapy has demonstrated a reduction in the number of inflammatory cells, including intimal and sublining macrophages, $\mathrm{T}$ cells, and plasma cells, in rheumatoid synovial tissue as soon as 48 hours after initiation of treatment [33]. Although unlicensed, intravenous administration of adalimumab also has demonstrated a rapid onset of clinical effect [38]. Whether intravenous administration of TNF antagonists has a faster effect than subcutaneous administration is not known presently, as no direct comparisons have been published.

Subcutaneous agents may be appropriate for and preferred by some patients. Although drug absorption into the bloodstream is slower and a delay of several days is possible before maximal concentrations are reached, desired outcomes can be achieved. While a rapid onset of effect for intravenous administration has been established, there is on average no clear-cut difference in longterm overall efficacy outcomes between subcutaneous and intravenous administration.

\section{Unmet needs in biologic therapy with TNF inhibitors}

Although TNF inhibitors are currently the gold standard of biologics for patients with inflammatory arthritides, there are still a number of outstanding questions regarding how to gain the maximum benefit from these agents. The most recent ACR guidance stating that patients with early RA are not candidates for biologic therapy [18] is debatable. There are convincing data indicating that the use of biologics early in the course of the disease can be highly efficacious and may induce clinical remission in a certain percentage of patients [13,15,39-41]. Additional data may spur modification of guidelines and practice for those early RA patients who do not respond sufficiently to conventional treatment. Of importance, a well-defined referral pathway within healthcare systems is needed to identify patients early in the course of the disease. Also, family physicians and other healthcare professionals must be educated about the early symptoms of inflammatory arthritides, with an emphasis on the importance of early referral to rheumatologists for diagnosis and treatment [42].

Likewise, additional studies are needed to determine whether patients with co-morbidities or those taking concurrent medications require monitoring for specific toxicities [4]. Several registries have reported a high prevalence of co-morbid conditions in RA patients who are commencing biologic therapy in routine practice $[43,44]$. Oldroyd and colleagues compared 354 patients with AS from the Australian Rheumatology Association Database who were commencing biologic therapy with more than 1,000 enrolees from four RCTs involving biologic therapy. At baseline, patients from the Australian Rheumatology Association Database - considered representative of the general population seeking clinical care - were found to have much higher levels of comorbidity than the RCT subjects, as well as significantly greater disease activity. These findings have important implications for patient monitoring [45].

In a broader sense, RA trial inclusion criteria may need to be less restrictive [46]. A comparison of $546 \mathrm{RA}$ patients from the Dutch Rheumatoid Arthritis Monitoring registry with 1,223 RA patients from 11 RCTs showed much greater disease activity at baseline in RCT enrolees [47]. The efficacy of TNF-blocking agents was lower in Dutch Rheumatoid Arthritis Monitoring registrants. For example, in 10 of the 11 comparisons, the ACR 20\% improvement criteria (ACR20) response rate was lower in the registry cohort (again, representative of daily 
clinical practice) than in the RCT group, and the difference was significant in five of the 11 comparisons. These data indicate a smaller, real-world effect of anti-TNF treatment than the effect seen in trials. The discrepancy may be due to continued use of co-medication and selection toward greater disease activity in RCTs.

Zink and colleagues obtained similar results during their comparison of 1,458 patients from the Rheumatoid Arthritis Observation of Biologic Therapy registry with data from five major RCTs that led to approval of biologics for RA. Only 21 to $33 \%$ of Rheumatoid Arthritis Observation of Biologic Therapy registrants would have been eligible for the trials, and this ineligible group demonstrated lower TNF inhibitor response rates than RCT enrolees who received biologic therapy. The investigators concluded that observational cohort studies, which include a full spectrum of patients (for example, with various co-morbidities, taking assorted concomitant medications), are essential to complement RCT data [46]. A study of 417 RA patients from the Danish Database for Biological Therapies in Rheumatology further supports these clinical practice data. In the majority of these routine care patients, TNF antagonists were not successful in controlling disease, although they did achieve moderate overall success in controlling clinical inflammation [48]. Clearly, a bridge is needed between trial results and real-world results.

Some studies have hypothesised that TNF inhibitors may have the potential to repair RA joint damage $[49,50]$. The data to support this notion are currently negligible, however, and tools to measure and evaluate repair must be developed before in-depth investigations can be launched.

\section{Potential for effectiveness of TNF antagonists in early rheumatoid arthritis}

In one study, a small number of patients experiencing RA symptoms for $<12$ months but considered to have a poor prognosis were randomised to receive either infliximab plus MTX $(n=10)$ or placebo plus MTX $(n=10)$ for 1 year [51]. Patients receiving infliximab experienced significant improvements in all measures at the end of year 1 compared with those receiving placebo. The infliximab patients then received MTX alone for an additional year, and $70 \%$ of patients maintained the infliximab responses, as measured by the C-reactive protein level, DAS in 28 joints (DAS28), and Health Assessment Questionnaire results [51].

van der Kooij and colleagues recently compared the clinical and radiological efficacy of initial $(n=117)$ versus delayed $(n=67)$ treatment with infliximab plus MTX in patients with early RA in a post hoc analysis of the BeSt study [52]. After 3 years of treatment, patients receiving initial infliximab plus MTX demonstrated more improvement in functional ability over time, as measured by the Health Assessment Questionnaire, and were less likely to have radiological progression than patients treated with delayed infliximab plus MTX. These results suggest that initial treatment with a biologic-plusDMARD combination in patients with recent-onset RA is more beneficial than reserving such treatment for patients in whom traditional DMARDs have failed [52].

The PREMIER study compared the efficacy of early intervention with a combination of adalimumab and MTX versus either agent used alone as monotherapy in patients with early, aggressive RA [15]. The primary end points in this 2-year, double-blind, controlled study $(n=799)$ were the percentage of patients in whom an ACR50 response was achieved and the mean change from baseline in the modified Total Sharp Score, which assesses bone erosion and joint space narrowing on radiographs. Combination therapy was superior to adalimumab and MTX monotherapy in all outcomes measured. At year 1, patients treated with combination therapy had a mean increase in Total Sharp Score of 1.3 units compared with 3.0 units in those receiving adalimumab monotherapy $(P=0.002)$ and of 5.7 units in those receiving MTX monotherapy $(P<0.001)$. At year 2 , patients receiving combination therapy continued to have significantly less radiographic progression (mean change 1.9 Sharp units) compared with those treated with either adalimumab (5.5 units) or MTX (10.4 units) monotherapy ( $P<0.001$ for both comparisons). Although ACR responses were comparable in the two monotherapy arms, there was significantly less progression in the adalimumab arm compared with the MTX arm at 6 months (2.1 vs. 3.5), 1 year (3.0 vs. 5.7) and 2 years (5.5 vs. 10.4) $(P<0.001$ for all comparisons). This is another study suggesting the value of combination therapy in early RA [15].

Van der Heijde and colleagues have hypothesized that therapeutic intervention early in the disease course has a disproportionate benefit on outcome if treatment is started early in the disease course [51]. Additionally, drug-free remission may be a realistic goal in some patients with early RA. In the BeSt study, $19 \%$ of patients who received infliximab plus MTX in a DAS-steered, tightly controlled manner were in drug-free remission at 5 years, for a mean duration of 22 months. Infliximab had been successfully discontinued in $58 \%$ of patients, while $18 \%$ were still receiving combination therapy. Furthermore, compared with other treatment strategies, initial temporary treatment with infliximab plus MTX resulted in significantly better functional ability over 5 years [53]. These studies raise the possibility that if aggressive treatment to induce remission is instituted very early in the course of RA, more conservative management strategies may be sufficient to maintain that remission. 
The use of TNF blockers for early-stage PsA is currently under discussion. For early-stage AS, one study showed infliximab to be highly efficacious in patients who were positive for HLA-B27, had recent-onset inflammatory back pain, and had early sacroiliitis demonstrated by magnetic resonance imaging [54].

\section{Prediction and discontinuation of TNF antagonists}

Additional unmet needs include: the ability to predict clinical response so that these drugs, which are expensive and have the potential for serious toxicity, can be targeted to patients who would most benefit [55]; an understanding of acquired drug resistance to anti-TNF agents [56]; a full explanation for why patients with spondyloarthritis (a group of disorders that includes AS and PsA) have a $20 \%$ lower probability of discontinuing TNF antagonists than patients with RA [57]; and an understanding of reasons for and predictors of discontinuation.

Relative to the first point, the search for predictors of response is important in the context of personalised medicine, with the aim of increasing the percentage of patients exhibiting a robust response to a given treatment. Wijbrandts and colleagues recently studied arthroscopic synovial tissue in 143 patients with active RA prior to initiating treatment with infliximab [58]. Their analysis confirmed that the baseline level of TNF expression may be a significant predictor of response to anti-TNF therapy. At baseline, TNF expression in the intimal lining layer and synovial sublining was significantly higher in responders than in nonresponders (clinical response determined at week 16$)(P=0.047$ and $P=0.008$, respectively). The number of macrophages, macrophage subsets, and $\mathrm{T}$ cells was also significantly higher in responders than in nonresponders [58]. The relationship between synovial lymphocyte aggregates and the clinical response to infliximab has also been studied in RA patients [59]. Synovial tissue biopsy samples were obtained from 97 patients with active RA before initiation of infliximab treatment. Lymphocyte aggregates were counted and graded for size, and logistic regression analysis identified whether the presence of lymphocyte aggregates could predict clinical response at week 16 . The majority (57\%) of RA synovial tissues contained lymphocyte aggregates. Additionally, aggregates were found in $67 \%$ of clinical responders compared with $38 \%$ of nonresponders. The presence of aggregates at baseline was a highly significant predictor of the clinical response to anti-TNF treatment $(P=0.008)$, demonstrating that RA patients with synovial lymphocyte aggregates may have a better response to infliximab treatment than those with only diffuse leucocyte infiltration [59].

Relative to the fourth point, 21 to $35 \%$ of patients discontinue TNF-blocking agents within the first year [60]. Reasons for discontinuation appear to include lack of response, loss of response, development of intolerance, partial efficacy, and adverse events [61,62]. Switching to a different TNF inhibitor may be an option for some patients [63]. One limited study with 31 enrolees suggested that when etanercept is not efficacious, infliximab may offer gains, and that when infliximab fails due to adverse events, etanercept may allow continuation [61]. Another larger study (complete data for 197 patients) in RA suggested that a second TNF inhibitor may be effective after failure of the first inhibitor, regardless of the reason for discontinuation of the first agent [60]. Conceivably, efficacy of a second TNF blocker may be lower in primary nonresponders to a first TNF blocker (response being defined at 12 to 16 weeks after initiation of treatment). Switching to a different mechanism of action and agent, such as rituximab, abatacept, or tocilizumab, is also an option (see below).

Identifying predictors of discontinuation would be valuable in managing disease and targeting therapies to patients most likely to benefit. Currently, treatment choices are dominated by patient and physician preference, side-effect profiles, and cost [64]. A cohort $(n=503)$ from the Brigham Rheumatoid Arthritis Sequential Study was examined to identify clinical predictors associated with discontinuation of TNF inhibitors [64]. In this study, 210 out of 503 patients (42\%) discontinued therapy. Unfortunately, only 63 patients gave a reason; the investigators therefore shifted to a model-based analysis. The results showed that higher risk of discontinuation was associated with prior use of another TNF agent. Lower risk of discontinuation was associated with longer disease duration, prior use of DMARDs, and longer MTX use.

More information is clearly needed with regard to individualising physician/patient decision-making about initiating anti-TNF agents, switching agents, and predicting efficacy and tolerability. Lowering the discontinuation rates is an important current goal.

\section{Newly discovered mechanisms of action}

More than 100 cytokines and chemokines have been identified in the inflammatory cascade associated with inflammatory arthritides [1]. Although TNF is a key player in the proinflammatory cytokine cascade, the complex interconnectivity and dynamics of cytokine biology mean that relationships between cytokines may be better visualised as a network within a cascade (Figure 1) [1,65].

Increased understanding of the pathophysiology of RA has led to the identification of new therapeutic targets, including proinflammatory cytokines, $\mathrm{T}$ cells and $\mathrm{B}$ cells, adhesion molecules, chemokines, and intracellular and extracellular signalling pathways. The first stage in the pathogenesis of RA is thought to be the activation of $\mathrm{T}$ cells via the T-cell receptor complex [66]. The second 


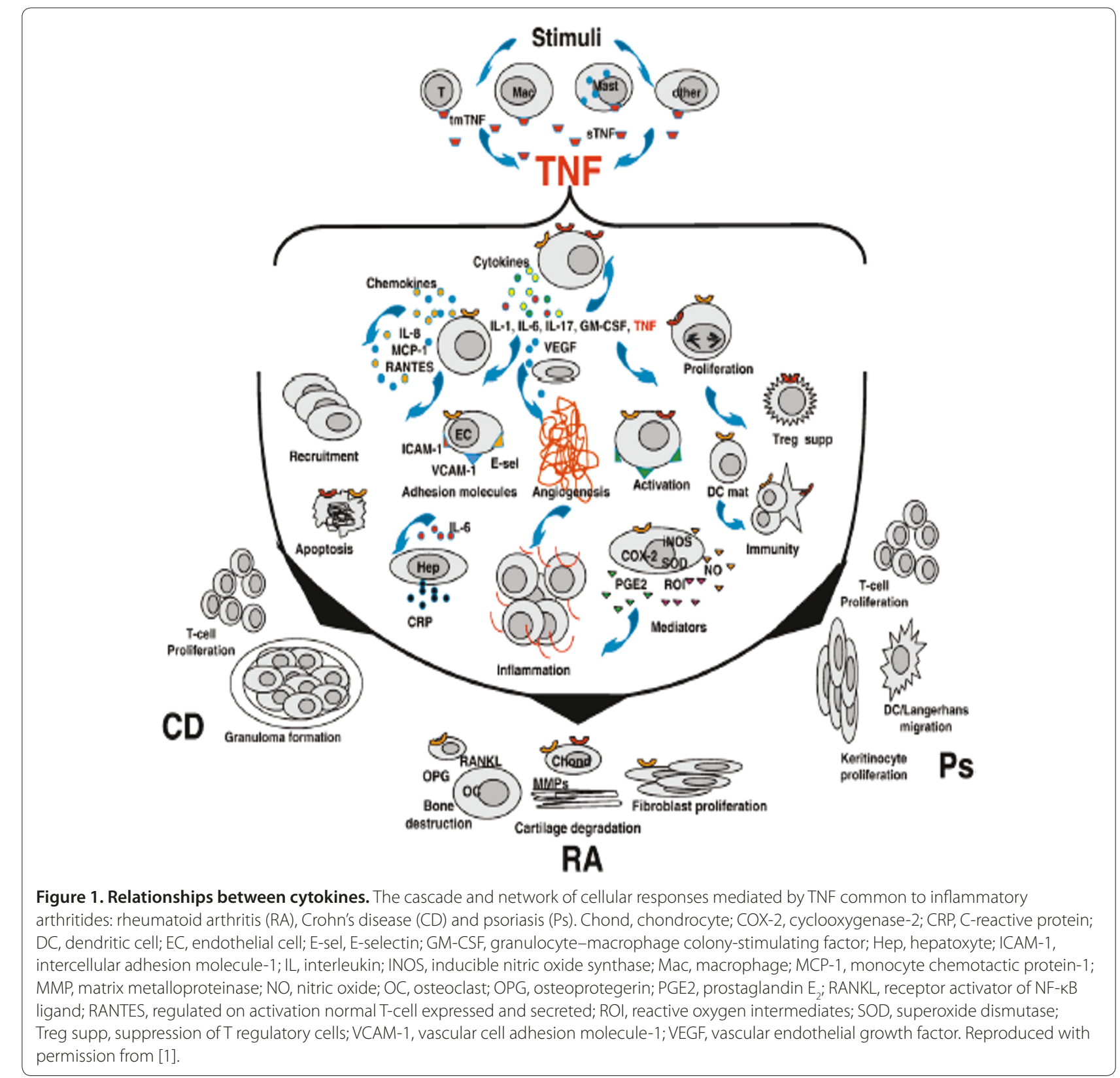

stage involves interaction between co-stimulatory molecules on $\mathrm{T}$ cells and molecules on antigen-presenting cells, providing more targets for intervention [66]. Fibroblast-like synoviocytes are resident mesenchymal cells of the synovial joints and are increasingly recognised as key players in the pathogenesis of RA. Activation of fibroblast-like synoviocytes produces a broad array of cell surface and soluble mediators that help to recruit, retain, and activate cells of the immune system and resident joint cells, leading to the promotion of ongoing inflammation and tissue destruction [67].

Cytokines such as IL-6, IL-12, IL-15, IL-17, IL-18, IL-21, IL-23, IL-33, and IFNץ provide potential targets for modulation [68], as do the signal transduction systems that follow the binding of cytokines to cell receptors, typically sequences of protein kinases such as mitogen-activated protein kinase [69]. Factors that modulate the transcription of genes following cytokine stimulation, such as NF-kB, provide more targets for modulation of cytokine pathways [70,71].

$B$ cells are also important in the pathophysiology of RA, although their role is not as well understood as that of $\mathrm{T}$ cells. $\mathrm{B}$ cells produce autoantibodies, may act as antigen-presenting cells, secrete proinflammatory cytokines such as IL-6, and regulate $\mathrm{T}$ cells. In addition to possibly acting as antigen-presenting cells, $\mathrm{B}$ cells produce 
immunoglobulins and secrete cytokines, perpetuating inflammation. Depletion of B cells is a logical therapeutic strategy that should provide a reduction in immunoinflammatory components [72,73]. B-cell-related potential targets include B-lymphocyte stimulator and the proliferation-inducing ligand APRIL. Both assist the survival, proliferation, and antigen presentation of $B$ cells. An exploratory phase IB trial of the recombinant fusion protein atacicept, which binds and neutralises B-lymphocyte stimulator and APRIL, was recently completed [74]. B cells also exhibit a regulatory capacity by controlling dendritic cell and T-cell function through cytokine production $[75,76]$. B-cell signalling pathways are emerging as potential therapeutic avenues. Targets include Bruton tyrosine kinase, which plays a key role in B-cell development and activation, and B-lymphocyte stimulator, which is important to B-cell survival and maturation [77].

Autoantibodies, such as anticitrullinated peptide antibodies and rheumatoid factor, serve as diagnostic and prognostic markers of RA. Their presence in a variety of autoimmune diseases suggests that they may also be valuable therapeutic targets. For example, blockade of Bcell trafficking may inhibit formation of autoantibodies [77]. This is an area ripe for investigation.

Other areas of research include modulating complement activation to prevent the influx of inflammatory cells into the synovium and inhibiting chemokines [78] to prevent the degradation of cartilage and bone [66]. The receptor activator of NF- $\mathrm{kB} /$ receptor activator of NF- $\mathrm{kB}$ ligand pathway is also being targeted with the aim of regulating the formation and activation of osteoclasts [79].

Lastly, although it is still unclear whether patients who fail one TNF blocker should switch to another TNF blocker or to a drug with a different mechanism of action, in RA in the recent past it has been common to try another TNF blocker after treatment with the first TNF blocker has failed [80]. However, it is possible that TNF is not the crucial cytokine instigating RA in primary nonresponders (patients with no response 12 to 16 weeks after initiation of therapy) to anti-TNF therapy $[58,80]$. Initial evidence that primary nonresponders are less likely to respond to a second TNF blocker may accelerate the search for non-TNF targets [80]. Consistent with this notion, lower synovial TNF expression and fewer TNFproducing inflammatory cells are, on average, present in primary nonresponders [58]. Pharmacokinetics and pharmacogenetics are expected to elucidate these concepts [81].

\section{Advances in biologic therapy}

There are many agents in development for the treatment of inflammatory arthritides. This is a highly competitive arena due to the complexity of interrelated pathways contributing to inflammatory arthritis pathogenesis [66]. Establishing the exact role of different treatments and identifying which patients will benefit most from them are the challenges now facing rheumatologists.

\section{Rituximab}

Rituximab, a chimeric anti-CD20 monoclonal antibody, was the first B-cell agent approved for treatment of RA [82]. This antibody was approved in combination with MTX in the United States and Europe in 2006 for adult patients with, respectively, moderate to severe active RA or severe active RA, after the failure of at least one TNF inhibitor. The agent targets B cells, rather than the entire immune system, and is administered by intravenous infusion to patients with an inadequate response to TNF inhibitors [83]. Rituximab has been shown to inhibit progression of structural damage in RA over 2 years, and continues to inhibit joint damage with long-term treatment $[39,84]$.

In the event of inadequate efficacy with a TNF inhibitor, some have suggested that switching patients to rituximab is a more effective management strategy than switching to another TNF inhibitor [85]. A prospective cohort study of 318 RA patients found that when the motive for switching to rituximab was TNF inhibitor ineffectiveness, disease improvement was significantly better than with an alternative TNF inhibitor [85]. If the reason for switching is not lack of efficacy (for example, adverse events, patient preference), there is no advantage in switching to rituximab [85].

Immunoglobulin levels have been found to be lower in patients receiving rituximab in the long term for RA [86]. An initial apparent trend toward higher rates of serious infection in this population may have been discounted by an open-label study of 1,039 RA patients [87]. The serious infection rate was 5.0 per 100 patient-years, similar to that for etanercept, infliximab, and adalimumab (5.3 per 100 patient-years) [88]. There also have been reports of psoriasis and PsA developing in RA patients receiving rituximab [89]; however, the same is true for TNF inhibitors [90]. The development of progressive multifocal leukoencephalopathy or hepatitis $B$ reactivation during rituximab treatment for RA is very rare.

\section{Abatacept}

Abatacept is a T-cell co-stimulation modulator administered by intravenous infusion. The modulator is thought to prevent the activation of $\mathrm{T}$ lymphocytes, including naïve $T$ cells $[91,92]$. Abatacept was approved in the United States and Europe in 2005 for treatment of RA in adult patients with an inadequate response to DMARDs or TNF inhibitors. In January 2010 it was approved in Europe for moderate-to-severe active polyarticular 
juvenile idiopathic arthritis in patients 6 years of age and older. Because abatacept was the first therapy targeting the inhibition of co-stimulatory signals to prevent T-cell activation, its use in early disease [93] and in biologicnaïve patients with active RA [94] has generated particular interest and investigation [91,95-97]. These data may support the use of abatacept in biologic-naïve patients with early disease who have had an inadequate response to MTX.

The magnitude of abatacept's effect appears to increase over time. According to the initial report of the Abatacept in Inadequate Responders to Methotrexate, Abatacept or Infliximab versus Placebo, a Trial for Tolerability, Efficacy, and Safety in Treating Rheumatoid Arthritis study, clinical response and disease activity were not only maintained from 6 to 12 months, but also appeared to improve [98]. The report containing 2-year results is currently only in abstract form but shows that reduced disease activity was maintained with ongoing abatacept treatment $[94,99]$. Abatacept has also demonstrated an increasing and significant degree of inhibition of structural damage progression in patients receiving treatment for 2 years [95]. Abatacept may have an increasing disease-modifying effect on structural damage over time in the majority of patients who respond to treatment. To date, this is a unique observation among biologic treatments for RA.

The long-term efficacy and safety of abatacept have been demonstrated over 5 years with a dose of $10 \mathrm{mg} / \mathrm{kg}$ [97]. In a long-term extension trial, abatacept was well tolerated and provided durable improvements in disease activity, with no unique safety events reported. These data, combined with relatively high retention rates, confirm that abatacept provides sustained clinical benefits in RA. Additionally, abatacept has been shown to provide clinical benefits in patients with RA who have previously failed TNF inhibitor treatment, regardless of the previous TNF inhibitor(s) used or the reason(s) for treatment failure [100]. This finding suggests that switching to abatacept may be a useful option for patients who fail TNF inhibitor treatment.

\section{Tocilizumab}

Tocilizumab is a humanised anti-IL-6-receptor monoclonal antibody administered by intravenous infusion. This antibody inhibits signals through both membrane and soluble IL-6 receptors [101]. Tocilizumab has received approval in Europe and the United States (January 2009 and 2010, respectively) for the treatment of moderate to severe RA in adult patients who have responded inadequately or have been intolerant to previous therapy with one or more DMARDs or TNF antagonists.

Tocilizumab used as monotherapy or in combination with MTX has demonstrated superiority over MTX monotherapy in reducing disease activity in RA over 24 weeks [102,103]. Furthermore, tocilizumab has resulted in significant improvements compared with placebo in physical function, fatigue, and physical and mental health scores over 24 weeks in patients who fail to respond to conventional DMARD therapy alone [104]. Tocilizumab has also demonstrated efficacy in RA patients who fail to achieve an adequate response with or became refractory to TNF inhibitors [105].

There is a close relationship between normalisation of serum IL-6 levels following treatment with tocilizumab and clinical remission. In the phase III SATORI trial, patients whose serum IL-6 levels became normal tended to achieve DAS28 remission. Normal IL-6 levels may therefore provide a good marker to identify patients who can stop tocilizumab treatment without the risk of flaring $[106,107]$.

In the 3-year extension of the SAMURAI study, patients with early RA treated with tocilizumab exhibited strongly suppressed radiographic progression [108]. Furthermore, radiographic progression was more effectively suppressed in patients who received tocilizumab at the start of the trial than in those who received conventional DMARDs at the start. Early introduction of tocilizumab treatment may therefore be more effective in preventing joint damage. The LITHE study in 1,196 patients who had inadequate responses to MTX further supports the potential for tocilizumab to suppress radiographic progression [109]. Patients also demonstrated improvements in physical function.

Tocilizumab has a well-characterised safety profile, with infections being the most common adverse event in trials [101,109]. Safety data pooled from five pivotal tocilizumab studies demonstrate rates of serious infection of 3.5 per 100 patient-years for the $4 \mathrm{mg} / \mathrm{kg}$ dose and of 4.9 per 100 patient-years for the $8 \mathrm{mg} / \mathrm{kg}$ dose compared with 3.4 per 100 patient-years for the comparator groups over a median 3.1 years' treatment duration [109]. Physicians should also monitor for decreased neutrophil counts and increased lipid or liver enzyme levels, and manage appropriately $[101,109]$.

\section{Certolizumab pegol}

Certolizumab is a pegylated Fab fragment of a humanised anti-TNF monoclonal antibody that neutralises the activity of TNF [66]. Certolizumab was approved for treatment of RA in combination with MTX in the United States and Europe in 2009. The use of pegylation increases the half-life of the molecule and eliminates the chimeric Fc portion. It is therefore hoped that adding polyethylene glycol will produce a longer-lasting compound with fewer side effects, although it remains to be established whether pegylation does indeed confer these advantages in clinical practice [66]. 
Subcutaneous administration of $400 \mathrm{mg}$ certolizumab every 4 weeks as monotherapy has demonstrated a rapid onset of response and reduction in RA disease activity as early as week 1 [110]. When used in combination with MTX, certolizumab (400 mg at baseline weeks 2 and 4, then 200 or 400 mg every 2 weeks) reduces radiographic progression compared with MTX alone over 1 year, and the difference is already significant at 6 months [111].

\section{Golimumab}

Golimumab is a fully human anti-TNF IgG monoclonal $_{1}$ antibody that targets and neutralises both the soluble and membrane-bound forms of TNF [66]. Golimumab was recently approved for monthly subcutaneous treatment of adults with RA, PsA, and AS. A randomised, doubleblind, placebo-controlled dose-ranging study compared subcutaneous injections of golimumab with placebo in patients with active RA despite treatment with MTX [112]. In this study, greater efficacy was demonstrated for golimumab $50 \mathrm{mg}$ every 4 weeks in addition to MTX compared with MTX plus placebo in terms of ACR responses. Furthermore, 20\% of patients receiving golimumab achieved DAS28 remission at week 16, compared with only $5.7 \%(P=0.074)$ of patients receiving MTX alone. Over a 52-week treatment period, all clinical responses achieved at week 16 were maintained and/or improved, and no unexpected safety issues were observed [112].

These results have been further confirmed in a phase III study in patients with established RA and disease activity despite treatment with MTX monotherapy [113]. Additionally, golimumab demonstrated efficacy in patients with established RA who had previously received other TNF inhibitors and in MTX-naïve patients $[114,115]$.

Efficacy has also been demonstrated in patients with PsA and AS treated with golimumab [116], similar to that for currently available TNF inhibitors $[117,118]$. Furthermore, golimumab is capable of increasing function in patients with AS [118]. In PsA, golimumab has also demonstrated improvements in psoriatic skin and nail disease [116].

\section{Ustekinumab}

Ustekinumab is a human monoclonal antibody directed against the p40 subunit of IL-12/IL-23 that has demonstrated efficacy in PsA [119]. In a parallel-group crossover study involving 146 patients, a significantly higher proportion of ustekinumab-treated patients achieved a response using ACR criteria compared with placebotreated patients at week 12. Ustekinumab was approved in 2009 in both the United States and Europe for treatment of patients with moderate-to-severe plaque psoriasis. Ustekinumab has not been approved for PsA.

\section{Kinase targets in development}

Kinases such as Janus kinase 3 are intracellular molecules that play a pivotal role in signal transduction of interleukins. CP-690550 is an oral Janus kinase inhibitor developed to interfere with these enzymes. In a recent study, 264 patients were randomised equally to receive placebo, $5 \mathrm{mg}$ CP-690550, $15 \mathrm{mg}$ CP-690550, or $30 \mathrm{mg}$ CP-690550 twice daily for 6 weeks and were followed for an additional 6 weeks after treatment. The primary efficacy endpoint was the ACR20 response rate at 6 weeks [120]. Response rates were 70.5\%, 81.2\%, and $76.8 \%$, respectively, in the groups receiving $5 \mathrm{mg}, 15 \mathrm{mg}$, and $30 \mathrm{mg}$ CP-690550 twice daily compared with $29.2 \%$ in the placebo group $(P<0.001)$. This study also assessed pain, physical functioning, and health status using 100-mm visual analogue scales, the Health Assessment Questionnaire - Disability Index, and the selfadministered Short-Form 36 [121]. Treatment with CP690550 resulted in clinically meaningful and statistically significant patient-reported improvements by week 1 of treatment. The incidence of blood lipid elevations and neutropaenia is concerning, however, and much longerterm studies are needed.

Also of interest are data indicating that spleen tyrosine kinase could serve as a novel and promising target for immune intervention in rheumatic diseases. R788, a novel and potent small-molecule spleen tyrosine kinase inhibitor, recently demonstrated the ability to ameliorate established diseases in lupus-prone NZB/NZW F1 mice and MRL/lpr mice, and also significantly reduced clinical arthritis in collagen-2-induced arthritis models [122,123]. In a recent 12-week double-blind study, 142 patients with active RA despite MTX therapy received R788 at concurrent doses of $50 \mathrm{mg}, 100 \mathrm{mg}$, or $150 \mathrm{mg}$ twice daily; 47 patients received MTX plus placebo [124]. The primary endpoint, an ACR20 response at week 12, was achieved by the majority of patients receiving $150 \mathrm{mg}$ or $100 \mathrm{mg}$ twice daily ( $72 \%$ vs. $65 \%$; $P<0.01)$. Around one-half of the patients achieved an ACR50 response (57\% vs. 49\%), and more than one-quarter of patients achieved an ACR70 response (40\% vs. 33\%). These results suggest that spleen tyrosine kinase inhibition is worthy of more in-depth study.

\section{Conclusion}

New approaches to inflammatory arthritides are challenging the rheumatologist. The advent of biologic therapies has revolutionised treatment and has allowed us to further influence the progression of these diseases as well as their symptoms. Development of the first biologics, TNF inhibitors, expanded our knowledge of the pathogenesis of inflammatory conditions. As TNF inhibitors have been available to rheumatologists for more than a decade, a large body of data has accumulated regarding 
their safety and efficacy. More recently, biologics with a distinct mechanism of action (rituximab, abatacept, and tocilizumab) have been approved. Numerous other targets within the inflammatory cascade continue to be identified, and biologic and nonbiologic agents to modulate/inhibit the associated pathways are either in the pipeline or have already been developed. The relative efficacy of these agents remains to be established, and, in time, head-to-head trials will be required to determine the best treatment options for patients.

An international task force comprising more than 60 rheumatology experts and a patient recently developed recommendations for achieving optimal therapeutic outcomes in RA. Using a Delphi-like procedure, the members discussed, amended, and voted on evidence derived from a systematic literature review as well as expert opinion. The resulting initiative, called Treat-toTarget, shares information and strategies in an effort to determine the best options for patients [125].

In the meantime, the prospect of preventing radiographic damage has led to a re-evaluation of how patients with inflammatory arthritides are managed, with early diagnosis and referral becoming increasingly important. Additionally, researchers are acknowledging specific subgroups of patients who are more likely to derive benefit from certain treatments. Before offering treatment options, the rheumatologist needs to be able to identify patients who are likely to respond to a particular treatment. This ability would allow optimal treatment to be initiated sooner, thereby potentially reducing the costs and the risks to patients and preventing radiological progression.

The search continues for biomarkers and molecular networks that can help us better understand the variable response to targeted therapy. Today, the key challenge facing rheumatologists is how best to integrate the advanced therapies into daily practice.

\section{Abbreviations \\ ACR, American College of Rheumatology; ACR20, American College of Rheumatology 20\% improvement criteria; APRIL, a proliferation-inducing ligand; AS, ankylosing spondylitis; DAS, Disease Activity Score; DMARD, disease-modifying antirheumatic drug; HLA, human leucocyte antigen; IFN, interferon; IL, interleukin; MTX, methotrexate; NF-KB, nuclear factor-KB; PsA, psoriatic arthritis; RA, rheumatoid arthritis; $\mathrm{RCT}$, randomised controlled trial; TNF, tumour necrosis factor.}

\section{Competing interests}

PPT has served as a consultant to Abbott, BMS, Merck-Serono, Pfizer, Roche, Schering-Plough and Wyeth. JRK has served as a consultant to Wyeth for Europe, and he lectures on behalf of Abbott, Pfizer, Roche and Wyeth.

\section{Acknowledgements}

Merck, Sharp \& Dohme Corporation (Whitehouse Station, NJ, USA) provided financial support for this article. Synergy Medical Education (Conshohocken, PA, USA) assisted in the preparation of the manuscript.

This article is part of Arthritis Research \& Therapy Volume 13 Supplement 1: The evolution of anti-TNF therapy in rheumatic disease: experience, insights and advances. The full contents of the supplement are available online at
http://arthritis-research.com/supplements/13/S1. Publication of this supplement is sponsored by Merck, Sharp \& Dohme Corporation, Whitehouse Station, New Jersey, USA.

\section{Author details}

'Department of Medicine, Division of Clinical Immunology and Rheumatology F4-105, Academic Medical Center/University of Amsterdam, P.O. Box 22700, 1100 DE Amsterdam, The Netherlands. ${ }^{2}$ Department of Internal Medicine III (Rheumatology and Immunology), Department for Molecular Immunology, Glueckstrasse 6, 91054 Erlangen, Germany.

Published: 25 May 2011

\section{References}

1. Tracey D, Klareskog L, Sasso EH, Salfeld JG, Tak PP: Tumor necrosis factor antagonist mechanisms of action: a comprehensive review. Pharmacol Ther 2008, 117:244-279.

2. Evangelisto $A$, Wakefield $R$, Emery P: Imaging in early arthritis. Best Pract Res Clin Rheumatol 2004, 18:927-943.

3. Combe B, Landewe R, Lukas C, Bolosiu HD, Breedveld F, Dougados M, Emery P, Ferraccioli G, Hazes JM, Klareskog L, Machold K, Martin-Mola E, Nielsen H, Silman A, Smolen J, Yazici H: EULAR recommendations for the management of early arthritis: report of a task force of the European Standing Committee for International Clinical Studies Including Therapeutics (ESCISIT). Ann Rheum Dis 2007, 66:34-45.

4. American College of Rheumatology Subcommittee on Rheumatoid Arthritis Guidelines: Guidelines for the management of rheumatoid arthritis: 2002 update. Arthritis Rheum 2002, 46:328-346.

5. Feldmann M, Brennan FM, Maini RN: Rheumatoid arthritis. Cell 1996, 85:307-310.

6. Braun J, Baraliakos X, Brandt J, Sieper J: Therapy of ankylosing spondylitis. Part II: biological therapies in the spondyloarthritides. Scand J Rheumatol 2005, 34:178-190.

7. Veale DJ, Ritchlin C, FitzGerald O: Immunopathology of psoriasis and psoriatic arthritis. Ann Rheum Dis 2005, 64(Suppl 2):ii26-ii29.

8. Choy EHS, Panayi GS: Cytokine pathways and joint inflammation in rheumatoid arthritis. N Engl J Med 2001, 344:907-916.

9. Enbrel (Etanercept). Summary of Product Characteristics [http://www. medicines.org.uk/emc/medicine/19161/SPC/Enbrel\%2025mg\%20 solution\%20for\%20injection\%20in\%20pre-filled\%20syringe]

10. Calabrese LH: Molecular differences in anticytokine therapies. Clin Exp Rheumatol 2003, 21:241-248.

11. Remicade (Infliximab). Summary of Product Characteristics [http://www.medicines.org.uk/EMC/medicine/3236/SPC/Remicade+100mg+ powder+for+concentrate+for+solution+for+infusion/]

12. Humira (Adalimumab). Summary of Product Characteristics [http://www. medicines.org.uk/emc/medicine/21201/SPC/Humira\%20Pen\%20and\%20 Syringe]

13. Emery P, Breedveld FC, Hall S, Durez P, Chang DJ, Robertson D, Singh A, Pedersen RD, Koenig AS, Freundlich B: Comparison of methotrexate monotherapy with a combination of methotrexate and etanercept in active, early, moderate to severe rheumatoid arthritis (COMET): a randomised, double-blind, parallel treatment trial. Lancet 2008, 372:375-382b.

14. Goekoop-Ruiterman YP, de Vries-Bouwstra JK, Allaart CF, van Zeben D, Kerstens PJ, Hazes JM, Zwinderman AH, Ronday HK, Han KH, Westedt ML, Gerards AH, van Groenendael JH, Lems WF, van Krugten MV, Breedveld FC, Dijkmans BA: Clinical and radiographic outcomes of four different treatment strategies in patients with early rheumatoid arthritis (the BeSt study): a randomized, controlled trial. Arthritis Rheum 2005, 52:3381-3390.

15. Breedveld FC, Weisman MH, Kavanaugh AF, Cohen SB, Pavelka K, van Vollenhoven R, Sharp J, Perez JL, Spencer-Green GT: The PREMIER study: a multicenter, randomized, double-blind clinical trial of combination therapy with adalimumab plus methotrexate versus methotrexate alone or adalimumab alone in patients with early aggressive rheumatoid arthritis who had not had previous methotrexate treatment. Arthritis Rheum 2006, 54:26-37.

16. Hochberg MC, Lebwohl MG, Plevy SE, Hobbs KF, Yocum DE: The benefit/risk profile of TNF-blocking agents: findings of a consensus panel. Semin Arthritis Rheum 2005, 34:819-836.

17. Schiff MH, Burmester GR, Kent JD, Pangan AL, Kupper H, Fitzpatrick SB, 
Donovan C: Safety analysis of adalimumab (HUMIRA ${ }^{\circ}$ ) in global clinical trials and US postmarketing surveillance of patients with rheumatoid arthritis. Ann Rheum Dis 2006, 65:889-894.

18. Saag KG, Teng GG, Patkar NM, Anuntiyo J, Finney C, Curtis JR, Paulus HE, Mudano A, Pisu M, Elkins-Melton M, Outman R, Allison JJ, Suarez Almazor M, Bridges SL Jr, Chatham WW, Hochberg M, MacLean C, Mikuls T, Moreland LW, O'Dell J, Turkiewicz AM, Furst DE; American College of Rheumatology: American College of Rheumatology 2008 recommendations for the use of nonbiologic and biologic disease-modifying antirheumatic drugs in rheumatoid arthritis. Arthritis Rheum 2008, 59:762-784.

19. Bellofiore B, Matarese A, Balato N, Gaudiello F, Scarpa R, Atteno M, Bocchino $M$, Sanduzzi A: Prevention of tuberculosis in patients taking tumor necrosis factor-alpha blockers. J Rheumatol 2009, 83:76-77.

20. Dixon WG, Hyrich KL, Watson KD, Lunt M, Galloway J, Ustianowski A; BSRBR Control Centre Consortium, Symmons DPM, on behalf of the BSR Biologics Register: Drug-specific risk of tuberculosis in patients with rheumatoid arthritis treated with anti-TNF therapy: results from the British Society for Rheumatology Biologics Register (BSRBR). Ann Rheum Dis 2010, 69:522-528.

21. Askling J, Fored CM, Brandt L, Baecklund E, Bertilsson L, Cöster L, Geborek P, Jacobsson LT, Lindblad S, Lysholm J, Rantapää-Dahlqvist S, Saxne T, Romanus V, Klareskog L, Feltelius N: Risk and case characteristics of tuberculosis in rheumatoid arthritis associated with tumor necrosis factor antagonists in Sweden. Arthritis Rheum 2005, 52:1986-1992.

22. Tubach F, Salmon D, Ravaud P, Allanore Y, Goupille P, Bréban M, Pallot-Prades B, Pouplin S, Sacchi A, Chichemanian RM, Bretagne S, Emilie D, Lemann M, Lorthololary O, Mariette X; RATIO group: Risk of tuberculosis is higher with anti-tumor necrosis factor monoclonal antibody therapy than with soluble tumor necrosis factor receptor therapy: the three-year prospective French Research Axed on Tolerance of Biotherapies registry. Arthritis Rheum 2009, 60:1884-1894.

23. Ellerin T, Rubin RH, Weinblatt ME: Infections and anti-tumor necrosis factor a therapy. Arthritis Rheum 2003, 48:3013-3022.

24. Bartelds GM, Wijbrandts CA, Nurmohamed MT, Stapel S, Lems WF, Aarden L, Dijkmans BA, Tak PP, Wolbink GJ: Clinical response to adalimumab: relationship to anti-adalimumab antibodies and serum adalimumab concentrations in rheumatoid arthritis. Ann Rheum Dis 2007, 66:921-926.

25. Wolbink GJ, Vis M, Lems W, Voskuyl AE, de Groot E, Nurmohamed MT, Stapel S, Tak PP, Aarden L, Dijkmans B: Development of anti-infliximab antibodies and relationship to clinical response in patients with rheumatoid arthritis. Arthritis Rheum 2006, 54:711-715.

26. van Kuijk AW, de Groot M, Stapel SO, Dijkmans BA, Wolbink GJ, Tak PP: Relationship between the clinical response to adalimumab treatment and serum levels of adalimumab and anti-adalimumab antibodies in patients with psoriatic arthritis. Ann Rheum Dis 2010, 69:624-625.

27. de Vries MK, van der Horst-Bruinsma IE, Nurmohamed MT, Aarden LA, Stapel SO, Peters MJ, van Denderen JC, Dijkmans BA, Wolbink GJ: Immunogenicity does not influence treatment with etanercept in patients with ankylosing spondylitis. Ann Rheum Dis 2009, 68:531-535.

28. de Vries MK, Wolbink GJ, Stapel SO, de Vrieze H, van Denderen JC, Dijkmans $B A$, Aarden $L A$, van der Horst-Bruinsma IE: Decreased clinical response to infliximab in ankylosing spondylitis is correlated with anti-infliximab formation. Ann Rheum Dis 2007, 66:1252-1254.

29. Zou J, Rudwaleit M, Brandt J, Thiel A, Braun J, Sieper J: Down-regulation of the non-specific and antigen-specific $T$ cell cytokine response in ankylosing spondylitis during treatment with infliximab. Arthritis Rheum 2003, 48:780-790

30. Zou J, Rudwaleit M, Brandt J, Thiel A, Braun J, Sieper J: Up regulation of the production of tumour necrosis factor alpha and interferon gamma by T cells in ankylosing spondylitis during treatment with etanercept. Ann Rheum Dis 2003, 62:561-564.

31. Wijbrandts CA, Remans PH, Klarenbeek PL, Wouters D, van den Bergh Weerman MA, Smeets TJ, Vervoordeldonk MJ, Baeten D, Tak PP: Analysis of apoptosis in peripheral blood and synovial tissue very early after initiation of infliximab treatment in rheumatoid arthritis patients. Arthritis Rheum 2008, 58:3330-3339

32. Scallon B, Cai A, Solowski N, Rosenberg A, Song XY, Shealy D, Wagner C: Binding and functional comparisons of two types of tumor necrosis factor antagonists. J Pharmacol Exp Ther 2002, 301:418-426.

33. Smeets TJ, Kraan MC, van Loon ME, Tak PP: Tumor necrosis factor alpha blockade reduces the synovial cell infiltrate early after initiation of treatment, but apparently not by induction of apoptosis in synovial tissue.
Arthritis Rheum 2003, 48:2155-2162.

34. Shergy WJ, Isern RA, Cooley DA, Harshbarger JL, Huffstutter JE, Hughes GM, Spencer-Smith EA, Goldman AL, Roth SH, Toder JS, Warner D, Quinn A, Keenan GF, Schaible TF; PROMPT Study Group: Profiling Remicade Onset with MTX in a Prospective Trial: open label study to assess infliximab safety and timing of onset of clinical benefit among patients with rheumatoid arthritis. J Rheumatol 2002, 29:667-677.

35. Charles P, Elliott MJ, Davis D, Potter A, Kalden JR, Antoni C, Breedveld FC, Smolen JS, Eberl G, deWoody K, Feldmann M, Maini RN: Regulation of cytokines, cytokine inhibitors, and acute-phase proteins following antiTNF-a therapy in rheumatoid arthritis. J Immuno/ 1999, 163:1521-1528.

36. Smolen JS, Han C, Bala M, Maini RN, Kalden JR, van der Heijde D, Breedveld FC, Furst DE, Lipsky PE; ATTRACT Study Group: Evidence of radiographic benefit of treatment with infliximab plus methotrexate in rheumatoid arthritis patients who had no clinical improvement: a detailed subanalysis of data from the anti-tumor necrosis factor trial in rheumatoid arthritis with concomitant therapy study. Arthritis Rheum 2005, 52:1020-1030.

37. Hermann J, Mueller T, Fahrleitner A, Dimai HP: Early onset and effective inhibition of bone resorption in patients with rheumatoid arthritis treated with the tumour necrosis factor alpha antibody infliximab. Clin Exp Rheumatol 2003, 21:473-476.

38. Den Broeder A, van de Putte L, Rau R, Schattenkirchner M, Van Riel P, Sander O, Binder C, Fenner H, Bankmann Y, Velagapudi R, Kempeni J, Kupper H: A single-dose, placebo-controlled study of the fully human anti-tumor necrosis factor-alpha antibody adalimumab (D2E7) in patients with rheumatoid arthritis. J Rheumatol 2002, 29:2288-2298.

39. Tak PP, Rigby WF, Rubbert-Roth A, Peterfy CG, van Vollenhoven RF, Stohl W, Hessey E, Chen A, Tyrrell H, Shaw TM: Inhibition of joint damage and improved clinical outcomes with rituximab plus methotrexate in early active rheumatoid arthritis: the IMAGE trial. Ann Rheum Dis 2011, 70:39-46.

40. van der Heijde D, Klareskog L, Rodriguez-Valverde V, Codreanu C, Bolosiu H, Melo-Gomes J, Tornero-Molina J, Wajdula J, Pedersen R, Fatenejad S; TEMPO Study Investigators: Comparison of etanercept and methotrexate, alone and combined, in the treatment of rheumatoid arthritis: two-year clinical and radiographic results from the TEMPO study, a double-blind, randomized trial. Arthritis Rheum 2006, 54:1063-1074.

41. van Vollenhoven RF, Ernestam S, Geborek P, Petersson IF, Cöster L, Waltbrand E, Zickert A, Theander J, Thörner A, Hellström H, Teleman A, Dackhammar C, Akre F, Forslind K, Ljung L, Oding R, Chatzidionysiou A, Wörnert M, Bratt J: Addition of infliximab compared with addition of sulfasalazine and hydroxychloroquine to methotrexate in patients with early rheumatoid arthritis (Swefot trial): 1-year results of a randomized trial. Lancet 2009. 374:459-466

42. Smolen JS, Landewé R, Breedveld FC, Dougados M, Emery P, Gaujoux-Viala C, Gorter S, Knevel R, Nam J, Schoels M, Aletaha D, Buch M, Gossec L, Huizinga T, Bijlsma JW, Burmester G, Combe B, Cutolo M, Gabay C, Gomez-Reino J, Kouloumas M, Kvien TK, Martin-Mola E, Mclnnes I, Pavelka K, van Riel P, Scholte M, Scott DL, Sokka T, Valesini G, et al.: EULAR recommendations for the management of rheumatoid arthritis with synthetic and biological disease-modifying antirheumatic drugs. Ann Rheum Dis 2010, 69:964-975.

43. Hetland ML, Christensen IJ, Tarp U, Dreyer L, Hansen A, Hansen IT, Kollerup G, Linde L, Lindegaard HM, Poulsen UE, Schlemmer A, Jensen DV, Jensen S, Hostenkamp G, Østergaard M; All Departments of Rheumatology in Denmark: Direct comparison of treatment responses, remission rates, and drug adherence in patients with rheumatoid arthritis treated with adalimumab, etanercept, or infliximab: results from eight years of surveillance of clinical practice in the nationwide Danish DANBIO registry. Arthritis Rheum 2010, 62:22-32.

44. Hyrich K, Symmons D, Watson K, Silman A: Baseline comorbidity levels in biologic and standard DMARD treated patients with rheumatoid arthritis: results from a national patient register. Ann Rheum Dis 2006, 65:895-898.

45. Oldroyd J, Schachna L, Buchbinder R, Staples M, Murphy B, Bond M, Briggs A, Lassere M, March L: Ankylosing spondylitis patients commencing biologic therapy have high baseline levels of comorbidity: a report from the Australian Rheumatology Association Database. Int J Rheumatol 2009, open access article available at http://www.hindawi.com/journals/ij/2009/268569/

46. Zink A, Strangfeld A, Schneider M, Herzer P, Hierse F, Stoyanova-Scholz M, Wassenberg S, Kapelle A, Listing J: Effectiveness of tumor necrosis factor inhibitors in rheumatoid arthritis in an observational cohort study: comparison of patients according to their eligibility for major randomized clinical trials. Arthritis Rheum 2006, 54:3399-3407. 
47. Kievit W, Fransen J, Oerlemans AJ, Kuper HH, van der Laar MA, de Rooij DJ, De Gendt CM, Ronday KH, Jansen TL, van Oijen PC, Brus HL, Adang EM, van Riel PL: The efficacy of anti-TNF in rheumatoid arthritis: a comparison between randomised controlled trials and clinical practice. Ann Rheum Dis 2007, 66:1473-1478.

48. Østergaard M, Unkerskov J, Linde L, Krogh NS, Ravn T, Ringsdal VS, Petri A, Andersen LS, Tarp U, Hansen A, Hjardem E, Hetland ML: Low remission rates but long drug survival in rheumatoid arthritis patients treated with infliximab or etanercept: results from the nationwide Danish DANBIO database. Scand J Rheumatol 2007, 36:151-154

49. Klinkhoff A: Biological agents for rheumatoid arthritis: targeting both physical function and structural damage. Drugs 2004, 64:1267-1283.

50. van der Heijde D, Kavanaugh A, Gladman DD, Antoni C, Krueger GG, Guzzo C, Zhou B, Dooley LT, de Vlam K, Geusens P, Birbara C, Halter D, Beutler A Infliximab inhibits progression of radiographic damage in patients with active psoriatic arthritis through one year of treatment. Results from the induction and maintenance psoriatic arthritis clinical trial 2. Arthritis Rheum 2007, 56:2698-2707.

51. Quinn MA, Conaghan PG, O'Connor PJ, Karim Z, Greenstein A, Brown A, Brown C, Fraser A, Jarret S, Emery P: Very early treatment with infliximab in addition to methotrexate in early, poor-prognosis rheumatoid arthritis reduces magnetic resonance imaging evidence of synovitis and damage, with sustained benefit after infliximab withdrawal. Results from a twelvemonth randomized, double-blind, placebo-controlled trial. Arthritis Rheum 2005, 52:27-35

52. van der Kooij SM, le Cessie S, Goekoop-Ruiterman YP, de Vries-Bouwstra JK, van Zeben D, Kerstens PJ, Hazes JM, van Schaardenburg D, Breedveld FC, Dijkmans BA, Allaart CF: Clinical and radiological efficacy of initial vs delayed treatment with infliximab plus methotrexate in patients with early rheumatoid arthritis. Ann Rheum Dis 2009, 68:1153-1158.

53. Klarenbeek NB, Guler-Yuksel M, van der Kooij SM, van der Heijde DMFM, Huizinga TWJ, Kerstens PJSM, Peeters AJ, Ronday HK, Westedt ML, Dijkmans BAC, Allart CF: Clinical outcomes of four different treatment strategies in patients with recent-onset rheumatoid arthritis: 5 -years results of the BeSt study [abstract]. Ann Rheum Dis 2008, 67(suppl II):187.

54. Barkham N, Keen HI, Coates LC, O'Connor P, Hensor E, Fraser AD, Cawkwell LS, Bennett $A$, McGonagle D, Emery P: Clinical and imaging efficacy of infliximab in HLA-B27-positive patients with magnetic resonance imaging-determined early sacroiliitis. Arthritis Rheum 2009, 60:946-954.

55. Hyrich K, Watson KD, Silman AJ, Symmons DPM; British Society for Rheumatology Biologics Register: Predictor of response to anti-TNF-a therapy among patients with rheumatoid arthritis: results from the British Society for Rheumatology Biologics Register. Rheumatology (Oxford) 2006, 45:1558-1565.

56. Finckh A, Simard JF, Gabay C, Guerne PA; Swiss Clinical Quality Management of RA Physicians: Evidence for differential acquired drug resistance to antitumour necrosis factor agents in rheumatoid arthritis. Ann Rheum Dis 2006, 65:746-752.

57. Carmona L, Gómez-Reino JJ: Survival of TNF antagonists in spondylarthritis is better than in rheumatoid arthritis. Data from the Spanish registry BIOBADASER. Arthritis Res Ther 2006, 8:R72.

58. Wijbrandts CA, Dijkgraaf MG, Kraan MC, Vinkenoog M, Smeets TJ, Dinant H, Vos K, Lems WF, Wolbink GJ, Sijpkens D, Dijkmans BA, Tak PP: The clinical response to infliximab in rheumatoid arthritis is in part dependent on pre-treatment tumour necrosis factor alpha expression in the synovium. Ann Rheum Dis 2008, 67:1139-1144.

59. Klaasen R, Thurlings RM, Wijbrandts CA, van Kuijk AW, Baeten D, Gerlag DM, Tak PP: The relationship between synovial lymphocyte aggregates and the clinical response to infliximab in rheumatoid arthritis: a prospective study. Arthritis Rheum 2009, 60:3217-3224

60. Blom M, Kievit W, Fransen J, Kuper IH, den Broeder AA, De Gendt CM, Jansen $T L$, Brus HL, van de Laar MA, van Riel PL: The reason for discontinuation of the first tumor necrosis factor (TNF) blocking agent does not influence the effect of a second TNF blocking agent in patients with rheumatoid arthritis. J Rheumato/ 2009, 36:2171-2177.

61. van Vollenhoven R, Harju A, Brannemark S, Klareskog L: Treatment with infliximab (Remicade) when etanercept (Enbrel) has failed or vice versa: data from the STURE registry showing that switching tumour necrosis factor alpha blockers can make sense. Ann Rheum Dis 2003, 62:1195-1198.

62. van Vollenhoven RF: Switching between anti-tumour necrosis factors: trying to get a handle on a complex issue. Ann Rheum Dis 2007, 66:849-851.
63. Keystone EC: Switching tumor necrosis factor inhibitors: an opinion. Nat Clin Pract Rheumatol 2006, 2:576-577.

64. Agarwal SK, Glass RJ, Shadick NA, Coblyn JS, Anderson RJ, Maher NE, Weinblatt ME, Solomon DH: Predictors of discontinuation of tumor necrosis factor inhibitors in patients with rheumatoid arthritis. J Rheumato/ 2008, 35:1737-1744

65. Feldmann M: Development of anti-TNF therapy for rheumatoid arthritis. Nat Rev Immunol 2002, 2:364-371.

66. Voulgari PV: Emerging drugs for rheumatoid arthritis. Expert Opin Emerging Drugs 2008, 13:175-196.

67. Noss EH, Brenner MB: The role and therapeutic implications of fibroblastlike synoviocytes in inflammation and cartilage erosion in rheumatoid arthritis. Immunol Rev 2008, 223:252-270.

68. Mclnnes IB, Schett G: Cytokines in the pathogenesis of rheumatoid arthritis. Nat Rev Immunol 2007, 7:429-442.

69. Ralph JA, Morand EF: MAPK phosphatases as novel targets for rheumatoid arthritis. Expert Opin Ther Targets 2008, 12:795-808.

70. Koczan D, Drynda S, Hecker M, Drynda A, Guthke R, Kekow J, Thiesen HJ: Molecular discrimination of responders and nonresponders to anti-TNFa therapy in rheumatoid arthritis by etanercept. Arthritis Res Ther 2008, 10:R50.

71. Tas SW, Vervoordeldonk MJ, Tak PP: Gene therapy targeting nuclear factorKB: towards clinical application in inflammatory diseases and cancer. Curr Gene Ther 2009, 9:160-170.

72. Dörner T, Kinnman N, Tak PP: Targeting B cells in immune-mediated inflammatory disease: a comprehensive review of mechanisms of action and identification of biomarkers. Pharmacol Ther 2010, 125:464-475.

73. Vischer TL, Werner-Favre CF, Wen L, Zubler RH: Quantitative analysis of precursors frequency of rheumatoid factor (RF) producing human B cells. Scand J Rheumatol Supp/ 1988, 75:123-126.

74. Tak PP, Thurlings RM, Rossier C, Nestorov I, Dimic A, Mircetic V, Rischmuelle M, Nasonov E, Shmidt E, Emery P, Munafo A: Atacicept in patients with rheumatoid arthritis: results of a multicenter, phase $\mathrm{lb}$, double-blind, placebo-controlled, dose-escalating, single- and repeated-dose study. Arthritis Rheum 2008, 58:61-72.

75. Youinou P, Jamin C, Saraux A: B-cell: a logical target for treatment of rheumatoid arthritis. Clin Exp Rheumatol 2007, 25:318-328.

76. Youinou P, Jamin C, Pers JO, Berthou C, Saraux A, Renaudineau Y: B-lymphocytes are required for development and treatment of autoimmune diseases. Ann N Y Acad Sci 2005, 1050:19-33.

77. Chaiamnuay S, Bridges SL Jr: The role of B cells and autoantibodies in rheumatoid arthritis. Pathophysiology 2005, 12:203-216.

78. Tak PP: Chemokine inhibition in inflammatory arthritis. Best Pract Res Clin Rheumatol 2006, 20:929-939.

79. Schett G: Review: immune cells and mediators of inflammatory arthritis. Autoimmunity 2008, 41:224-229.

80. Bartelds GM, Wijbrandts CA, Nurmohamed MT, Stapel SO, Lems WF, Aarden L, Dijkmans BA, Tak PP, Wolbink GJ: Anti-infliximab and anti-adalimumab antibodies in relation to response to adalimumab in infliximab switchers and anti-TNF naive patients: a cohort study. Ann Rheum Dis 2010, 69:817-821.

81. Coenen MJ, Toonen EJ, Scheffer H, Radstake TR, Barrera P, Franke B: Pharmacogenetics of anti-TNF treatment in patients with rheumatoid arthritis. Pharmacogenomics 2007, 8:761-773.

82. Cohen SB, Emery P, Greenwald MW, Dougados M, Furie RA, Genovese MC, Keystone EC, Loveless JE, Burmester GR, Cravets MW, Hessey EW, Shaw T, Totoritis MC; REFLEX Trial Group: Rituximab for rheumatoid arthritis refractory to anti-tumor necrosis factor therapy: results of a multicenter, randomized, double-blind, placebo-controlled, phase III trial evaluating primary efficacy and safety at twenty-four weeks. Arthritis Rheum 2006, 54:2793-2806

83. MabThera (Rituximab). Summary of Product Characteristics [http://www.medicines.org.uk/EMC/medicine/2570/SPC/Mabthera+100mg+ and+500mg+concentrate+for+solution+for+infusion/]

84. Keystone E, Emery P, Peterfy CG, Tak PP, Cohen S, Genovese MC, Dougados M, Burmester GR, Greenwald M, Kvien TK, Williams S, Hagerty D, Cravets MW, Shaw T: Rituximab inhibits structural joint damage in patients with rheumatoid arthritis with an inadequate response to tumour necrosis factor inhibitor therapies. Ann Rheum Dis 2009, 68:216-221.

85. Finckh A, Ciurea A, Brulhart L, Möller B, Walker UA, Courvoisier D, Kyburz D, Dudler J, Gabay C; Swiss Clinical Quality Management Programme for 
Rheumatoid Arthritis: Which subgroup of patients with rheumatoid arthritis benefits from switching to rituximab versus alternative antitumour necrosis factor (TNF) agents after previous failure of an anti-TNF agent? Ann Rheum Dis 2010, 69:387-393.

86. Kormelink TG, Tekstra J, Thurlings RM, Boumans MH, Vos K, Tak PP, Bijlsma JW Lafeber FP, Redegeld FA, van Roon JA: Decrease in immunoglobulin free light chains in patients with rheumatoid arthritis upon rituximab (antiCD20) treatment correlates with decrease in disease activity. Ann Rheum Dis 2010, 69:2137-2144.

87. Keystone E, Fleischmann R, Emery P, Furst DE, van Vollenhoven R, Bathon J, Dougados M, Baldassare A, Ferraccioli G, Chubick A, Udell J, Cravets MW, Agarwal A, Cooper S, Magrini F: Safety and efficacy of additional courses of rituximab in patients with active rheumatoid arthritis: an open-label extension analysis. Arthritis Rheum 2007, 56:3896-3908.

88. Dixon WG, Watson K, Lunt M, Hyrich KL, Silman AJ, Symmons DP; British Society for Rheumatology Biologics Register: Rates of serious infection including site-specific and bacterial intracellular infection, in rheumatoid arthritis patients receiving anti-tumor necrosis factor therapy: results from the British Society for Rheumatology Biologics Register. Arthritis Rheum 2006, 54:2368-2376

89. Dass S, Vital EM, Emery P: Development of psoriasis after B cell depletion with rituximab. Arthritis Rheum 2007, 56:2715-2718.

90. Ko JM, Gottlieb AB, Kerbleski JF: Induction and exacerbation of psoriasis with TNF-blockade therapy: a review and analysis of 127 cases. J Dermatolog Treat 2009, 20:100-108.

91. Emery P, Durez P, Dougados M, Legerton CW, Becker JC, Vratsanos G, Genant HK, Peterfy C, Mitra P, Overfield S, Qi K, Westhovens R: Impact of T-cell costimulation modulation in patients with undifferentiated inflammatory arthritis or very early rheumatoid arthritis: a clinical and imaging study of abatacept (the ADJUST trial). Ann Rheum Dis 2010, 69:510-516.

92. Orencia (Sbatacept). Summary of Product Characteristics [http://www.medicines.org.uk/EMC/medicine/19714/SPC/ORENCIA+250+ mg+powder+for+concentrate+for+solution+for+infusion/]

93. Voll RE, Kalden JR: Do we need new treatment that goes beyond tumor necrosis factor blockers for rheumatoid arthritis? Ann NY Acad Sci 2005, 1051:799-810

94. Schiff M, Bessette L: Evaluation of abatacept in biologic-naïve patients with active rheumatoid arthritis [includes some 2-year data from ATTEST trial]. Clin Rheumatol 2010, 29:583-591.

95. Genant HK, Peterfy CG, Westhovens R, Becker J-C, Aranda R, Vratsanos G, Teng J, Kremer JM: Abatacept inhibits progression of structural damage in rheumatoid arthritis: results from the long-term extension of the AIM trial. Ann Rheum Dis 2008, 67:1084-1089.

96. Genovese MC, Schiff M, Luggen M, Becker J-C, Aranda R, Teng J, Li T, Schmidely N, Le Bars M, Dougados M: Efficacy and safety of the selective co-stimulation modulator abatacept following 2 years of treatment in patients with rheumatoid arthritis and an inadequate response to antitumour necrosis factor therapy. Ann Rheum Dis 2008, 67:547-554.

97. Westhovens R, Kremer J, Moreland L, Emery P, Russell A, Li T, Aranda R, Becker J-C, Qi K, Dougados M: Safety and efficacy of the selective costimulation modulator abatacept in patients with rheumatoid arthritis receiving background methotrexate: a 5-year extended phase IIB study. J Rheumatol 2009, 36:736-742.

98. Schiff M, Keiserman M, Codding C, Songcharoen S, Berman A, Nayiager S, Saldate C, Li T, Aranda R, Becker J-C, Lin C, Cornet PLN, Dougados M: Efficacy and safety of abatacept or infliximab vs placebo in ATTEST: a phase III, multi-centre, randomised, double-blind, placebo-controlled study in patients with rheumatoid arthritis and an inadequate response to methotrexate [1-year results]. Ann Rheum Dis 2008, 67:1096-1103.

99. Schiff M, Keiserman M, Codding C, Songcharoen S, Berman A, Nayiager S, Saldate C, Aranda R, Becker JC, Zhao C, Le Bars M, Dougados M: Two-year efficacy and safety in abatacept-treated patients with RA who received continuous therapy or switched from infliximab to abatacept: the ATTEST trial [abstract]. Ann Rheum Dis 2009, 38:575.

100. Schiff M, Pritchard C, Huffstutter JE, Rodriguez-Valverde V, Durez P, Zhou X, Li T, Bahrt K, Kelly S, Le Bars M, Genovese MC: The 6-month safety and efficacy of abatacept in patients with rheumatoid arthritis who underwent a washout after anti-tumour necrosis factor therapy or were directly switched to abatacept: the ARRIVE trial. Ann Rheum Dis 2009, 68:1708-1714.

101. RoActemra (Tocilizumab). Summary of Product Characteristics [http://www.medicines.org.uk/EMC/medicine/22312/PIL/RoActemra+20mg $+\mathrm{ml}+$ Concentrate+for+Solution+for+Infusion/]

102. Jones G: The AMBITION trial: tocilizumab monotherapy for rheumatoid arthritis. Expert Rev Clin Immunol 2010, 6:189-195.

103. Smolen JS, Beaulieu A, Rubbert-Roth A, Ramos-Remus C, Rovensky J, Alecock E, Woodworth T, Alten R; OPTION Investigators: Effect of interleukin-6 receptor inhibition with tocilizumab in patients with rheumatoid arthritis (OPTION study): a double-blind, placebo-controlled, randomised trial. Lancet 2008, 371:987-997.

104. Gomez-Reino JJ, Fairfax MJ, Pavelka K, Alecock E, Woodworth T, Genovese M: Targeted inhibition of IL-6 signalling with tocilizumab improves quality of life and function in patients with rheumatoid arthritis with inadequate response to a range of DMARDs [abstract]. Arthritis Rheum 2007, 56(I2):4234.

105. Emery P, Keystone E, Tony H, Cantagrel A, van Vollenhoven R, Sanchez A, Alecock E, Lee J, Kremer J: IL-6 receptor inhibition with tocilizumab improves treatment outcomes in patients with rheumatoid arthritis refractory to anti-tumour necrosis factor biologicals: results from a 24-week multicentre randomised placebo-controlled trial [RADIATE study]. Ann Rheum Dis 2008, 67:1516-1523.

106. Nishimoto N: Interleukin-6 as a therapeutic target in candidate inflammatory diseases. Clin Pharmacol Ther 2010, 87:483-487.

107. Nishimoto N, Miyasaka N, Yamamoto K, Kawai S, Takeuchi T, Azuma J, Kishimoto T: Study of active controlled tocilizumab monotherapy for rheumatoid arthritis patients with an inadequate response to methotrexate (SATORI): significant reduction in disease activity and serum vascular endothelial growth factor by IL-6 receptor inhibition therapy. Mod Rheumatol 2009, 19:12-19.

108. Hashimoto J, Garnero P, van der Heijde D, Miyasaka N, Yamamoto K, Kawai S, Takeuchi T, Yoshikawa H, Nishimoto N: Humanized anti-interleukin-6receptor antibody (tocilizumab) monotherapy is more effective in slowing radiographic progression in patients with rheumatoid arthritis at high baseline risk for structural damage evaluated with levels of biomarkers, radiography, and BMI: data from the SAMURAI study. Mod Rheumatol 2011 [Epub ahead of print]

109. Kremer JL, Blanco R, Brzosko M, Burgos-Vargas R, Halland AM, Vernon E, Ambs $P$, Fleischmann R: Tocilizumab inhibits structural joint damage in rheumatoid arthritis patients with inadequate responses to methotrexate at 1 year: the LITHE study. Arthritis Rheum 2011, 63:609-621.

110. Fleischmann R, Vencovsky J, van Vollenhoven RF, Borenstein D, Box J, Coteur G, Goel N, Brezinschek HP, Innes A, Strand V: Efficacy and safety of certolizumab pegol monotherapy every 4 weeks in patients with rheumatoid arthritis failing previous disease-modifying antirheumatic therapy: the FAST4WARD study. Ann Rheum Dis 2009, 68:805-811.

111. Smolen J, Landewé RB, Mease P, Brzezicki J, Mason D, Luijtens $K$, van Vollenhoven RF, Kavanaugh A, Schiff M, Burmester GR, Strand V, Vencovsky J, van der Heijde D: Efficacy and safety of certolizumab pegol plus methotrexate in active rheumatoid arthritis: the RAPID 2 study. A randomised controlled trial. Ann Rheum Dis 2009, 68:797-804.

112. Kay J, Matteson EL, Dasgupta B, Nash P, Durez P, Hall S, Hsia EC, Han J, Wagner C, Xu Z, Visvanathan S, Rahman MU: Golimumab in patients with active rheumatoid arthritis despite treatment with methotrexate: a randomized, double-blind, placebo-controlled, dose-ranging study. Arthritis Rheum 2008, 58:964-975.

113. Keystone EC, Genovese MC, Klareskog L, Hsia EC, Hall ST, Miranda PC, Pazdur J, Bae SC, Palmer W, Zrubek J, Wiekowski M, Visvanathan S, Wu Z, Rahman MU: Golimumab, a human antibody to tumour necrosis factor a given by monthly subcutaneous injections, in active rheumatoid arthritis despite methotrexate therapy: the GO-FORWARD Study. Ann Rheum Dis 2009, 68:789-796.

114. Smolen J, Kay J, Doyle MK, Landewe R, Matteson EL, Wollenhaupt J, Gaylis N, Murphy F, Neal J, Zamani O, Zhou Y, Visvanathan S, Hsia EC, Rahman MU; GO-AFTER Study Investigators: Golimumab in patients with active rheumatoid arthritis after treatment with tumour necrosis factor a inhibitors (GO-AFTER study): a multicentre, randomised, double-blind, placebo-controlled, phase III trial. Lancet 2009, 374:210-221.

115. Emery P, Fleischmann RM, Moreland LW, Hsia EC, Strusberg I, Durez P, Nash P, Amante E, Churchill M, Park W, Pons-Estel B, Xu W, Rahman MU: Golimumab, a human anti-tumor necrosis factor a monoclonal antibody, injected subcutaneously every four weeks in methotrexate-naive patients with active rheumatoid arthritis [GO-BEFORE study]. Arthritis Rheum 2009, 60:2272-2283. 
116. Kavanaugh A, McInnes I, Mease P, Krueger GG, Gladman D, Gomez-Reino J, Papp K, Zrubek J, Mudivarthy S, Mack M, Visvanathan S, Beutler A:

Golimumab, a new human tumor necrosis factor a antibody, administered every four weeks as a subcutaneous injection in psoriatic arthritis: twentyfour-week efficacy and safety results of a randomized, placebo-controlled study. Arthritis Rheum 2009, 60:976-986.

117. Braun J, Davis JC, van der Heijde D, Deodhar A, Diekman L, Sieper J, Kim SII, Mack M, Han J, Hsu B, Beutler A, Inman R: Golimumab, a new, human, TNF-alpha antibody administered subcutaneously every 4 weeks, in ankylosing spondylitis (AS): 24-week efficacy and safety results of the randomized, placebo-controlled GO-RAISE study [abstract]. Ann Rheum Dis 2008, 67(Suppl II):58.

118. Inman RD, Davis JC Jr, van der Heijde D, Diekman L, Sieper J, Kim SI, Mack M, Han J, Visvanathan S, Xu Z, Hsu B, Beutler A, Braun J: Efficacy and safety of golimumab in patients with ankylosing spondylitis: results of a randomized, double-blind, placebo-controlled, phase III trial [GO-RAISE]. Arthritis Rheum 2008, 58:3402-3412.

119. Gottlieb A, Korman NJ, Gordon KB, Feldman SR, Lebwohl M, Koo JY, Van Voorhees AS, Elmets CA, Leonardi CL, Beutner KR, Bhushan R, Menter A: Guidelines of care for the management of psoriasis and psoriatic arthritis. Section 2. Psoriatic arthritis: overview and guidelines of care for treatment with an emphasis on the biologics. J Am Acad Dermatol 2008, 58:851-864.

120. Kremer JM, Bloom BJ, Breedveld FC, Coombs JH, Fletcher MP, Gruben D, Krishnaswami S, Burgos-Vargas R, Wilkinson B, Zerbini CAF, Zwillich SH: The safety and efficacy of a JAK inhibitor in patients with active rheumatoid arthritis: results of a double-blind, placebo-controlled phase lla trial of three dosage levels of CP-690,550 versus placebo. Arthritis Rheum 2009, 60:1895-1905

121. Coombs JH, Bloom BJ, Breedveld FC, Fletcher MP, Gruben D, Kremer JM, Burgos-Vargas R, Wilkinson B, Zerbini CA, Zwillich SH: Improved pain, physical functioning and health status in patients with rheumatoid arthritis treated with CP-690,550, an orally active Janus kinase (JAK) inhibitor: results from a randomised, double-blind, placebo-controlled trial. Ann Rheum Dis 2010, 69:413-416.

122. Bahjat FR, Pine PR, Reitsma A, Cassafer G, Baluom M, Grillo S, Chang B, Zhao FF, Payan DG, Grossbard EB, Daikh DI: An orally bioavailable spleen tyrosine kinase inhibitor delays disease progression and prolongs survival in murine lupus. Arthritis Rheum 2008, 58:1433-1444

123. Pine PR, Chang B, Schoettler N, Banquerigo ML, Wang S, Lau A, Zhao F, Grossbard EB, Payan DG, Brahn E: Inflammation and bone erosion are suppressed in models of rheumatoid arthritis following treatment with a novel Syk inhibitor. Clin Immunol 2007, 124:244-257.

124. Weinblatt ME, Kavanaugh A, Burgos-Vargas R, Dikranian AH, MedranoRamirez G, Morales-Torres JL, Murphy FT, Musser TK, Straniero N, VicenteGonzales AV, Grossbard E: Treatment of rheumatoid arthritis with a Syk kinase inhibitor: a twelve-week, randomized, placebo-controlled trial. Arthritis Rheum 2008, 58:3309-3318.

125. Smolen JS, Aletaha D, Bijlsma JW, Breedveld FC, Boumpas D, Burmester G, Combe B, Cutolo M, de Wit M, Dougados M, Emery P, Gibofsky A, GomezReino JJ, Haraoui B, Kalden J, Keystone EC, Kvien TK, McInnes I, Martin-Mola E, Montecucco C, Schoels M, van der Heijde D; T2T Expert Committee: Treating rheumatoid arthritis to target: recommendations of an international task force. Ann Rheum Dis 2010, 69:631-637.

doi:10.1186/ar3096

Cite this article as: Tak PP, Kalden JR: Advances in rheumatology: new targeted therapeutics. Arthritis Research \& Therapy 2011, 13(Suppl 1):S5. 